\title{
METODE VARIABEL COSTING GUNA PENENTUAN HARGA JUAL PADA UD. SEJAHTERA DESA SERUT PANTI
}

\author{
ACHADYAH PRABAWATI* \\ ABDUL GHOVUR HASBIYALLAH \\ Program Studi Ilmu Administrasi Niaga \\ Sekolah Tinggi Ilmu Administrasi Pembangunan Jember \\ *Email: achadyah@stiapembangunanjember.ac.id
}

\begin{abstract}
ABSTRAK
Penetapan harga jual yang dilakukan oleh manajer merupakan keputusan yang harus mempertimbangkan tidak hanya keuntungan saja, namun juga kelangsungan hidup perusahaan, berpedoman dengan pengeluaran biaya, dan tetap menjaga kesejahteraan karyawan. Dengan banyaknya hal yang harus diperhitungkan perlu adanya metode untuk membantu manajer mengambil keputusan menentukan harga jual. Metode variable costing membuat manajer mampu untuk memperbaiki penelusuran biaya dengan cara memfokuskan pada biaya yang berperilaku variabel terhadap pembentukan produk dan jasa.

Penelitian ini memiliki tujuan untuk mengetahui bagaimana metode variable costing apabila diterapkan pada UD. Sejahtera dalam menetukan harga jual. Jenis penelitian ini adalah penelitian kualitatif dengan pendekatan studi kasus. Metode pengumpulan data yang digunakan adalah dokumentasi, wawancara dan observasi. Jenis data yang digunakan adalah data primer dan data sekunder, sedangkan metode analisanya menggunakan analisa kualitatif.

Hasil penelitian ditemukan bahwa UD. Sejahtera terlalu tinggi dalam menetukan harga jual sehingga menyebabkan melemahnya pemasaran, akibatnya jumlah tenaga kerja ikut berkurang yang mengakibatkan produktivitas tempat usaha menurun. Setelah penulis melakukan analisa diketahui metode variabel costing lebih tepat digunakan pada UD. Sejahtera hal ini dibuktikan berdasarkan HPP dan harga jual antara metode variable costing dapat dijadikan tolok ukur atau batas minimal perolehan laba, selain

itu presentase mark up-nya lebih tinggi jika dibndingkan metode lain yaitu metode full costing.
\end{abstract}

Kata Kunci: Metode Variabel Costing, Penentuan Harga Jual 


\section{PENDAHULUAN}

Penetapan harga jual merupakan salah satu tugas manajer dalam mengambil keputusan demi kelangsungan hidup perusahaan. Maka penetapan harga jual harus berpedoman dengan pengeluaran biaya. Untuk itu perhitungan biaya produksi harus diperhatikan namun tidak menurunkan kualitas produk karena kualitas produk yang bagus maka akan menjaga keberlanjutan penjualan perusahaan.

Menurut Mulyadi (2007), ada beberapa metode dalam penetapan harga jual, diantaranya adalah: 1) penetapan harga normal (normal pricing); 2) cost type contract; 3) harga jual khusus (special order pricing); 4) penentuan harga yang diatur pemerintah; dan 5) profit margin. Penetapan harga jual menurut Mulyadi (2007) dapat dilakukan dengan menambahkan harga produk dengan taksiran atas tambahan biaya, yang merupakan persentase atas dasar biaya produk. Tambahan biaya ini disebut dengan mark up yaitu cost-plus pricing atas taksiran tambahan dari biaya penuh. Mark up ini dapat dilakukan dengan dua pendekatan yaitu full costing dan variable costing.

Menurut Samryn (2012:78-79), laporan yang menggunakan metode full costing apabila dibandingkan dengan metode variable costing maka lebih banyak memberikan manfaat bagi keperluan internal manajemen, diantaranya adalah laba periodik tidak dipengaruhi oleh tingkat persediaan. Variable costing mempunyai biaya produksi/unit tidak mengandung biaya tetap. Biaya pabrik dan laporan laba rugi dengan variable costing sesuai pemikiran manajemen karena pendekatan variable costing dapat mengidentifikasi biaya yang dapat dan tidak dapat dikendalikan dalam jangka pendek. Data variable costing relatif memudahkan penilaian kinerja menurut produk, wilayah, kelas pelanggan dan segmen lain dalam bisnis.

Berdasarkan perbandingan diatas penulis tertarik melakukan analisis penetapan harga dengan metode variable costing. Hal ini dikarenakan menurut Garrison dan Norren (2001:591) bahwa metode 
variable costing membuat manajemen mampu untuk memperbaiki penelusuran biaya dengan cara memfokuskan pada biaya yang berperilaku variabel terhadap pembentukan produk dan jasa.

Peneliti melakukan penelitian pada UD. Sejahtera Panti karena merupakan salah satu tempat usaha yang sudah lama menjalankan usaha di bidang home industry pembuatan alat dapur.

Berdasarkan observasi dan wawancara awal menemukan beberapa permasalahan yang dimulai dari harga bahan baku utama yakni alumunium yang terus naik. Bahan baku dari tahun 2016 sampai tahun 2017 meningkat $41 \%$ dan tahun berikutnya meningkat lagi $11 \%$ dari harga sebelumnya. Hal ini berpengaruh terhadap harga jual produk. Apabila peningkatan harga jual produk sesuai dengan peningkatan harga bahan baku maka dapat dipastikan penjualan hasil produksi sangat menurun. Untuk menghindari penurunan penjualan hasil produksi maka perusahaan melakukan strategi penjualan.
Adapun strategi penjualan yang dilakukan adalah melakukan peningkatan harga penjualan secara bertahap dengan persentase peningkatan setiap tahunnya dengan rata-rata peningkatan yaitu $16 \%$ sampai dengan $26 \%$.

Sehingga berdasarkan hal tersebut menunjukkan bahwa dengan peningkatan harga bahan baku akan meningkatkan biaya produksi. Peningkatan biaya produksi maka akan meningkatkan harga jual hasil produksi. Sementara jika terjadi peningkatan harga jual hasil produksi maka akan menurunkan permintaan konsumen. Penurunan permintaan konsumen akan meningkatkan penawaran, sehingga dapat dikatakan terjadi penurunan pasar.

Dengan penurunan pasar maka akan terjadi penurunan keuntungan usaha yang bahkan dapat menyebabkan perusahaan kehilangan pangsa pasar. Untuk menghindari kondisi tersebut maka harus mengkaji bagaimana meminimalisasi biaya produksi tanpa menurunkan kualitas produk sehingga tidak menurunkan minat beli dan kepuasan konsumen UD. Sejahtera. 
Selain beberapa masalah yang ditemukan peneliti, ada beberapa penelitian terdahulu yang sebelumnya juga melakukan penelitian tentang harga jual dengan metode yang sama yaitu metode variabel costing dengan tempat, waktu dan masalah yang berbeda.

Penelitian terdahulu yang mengkaji metode yang sama yaitu Kabib dkk (2017), Sari dan Fazli (2016), dan Megawati (2018), Pada penelitian Megawati (2018), tempat yang diteliti menghadapi masalah dimana harga yang terlalu tinggi menyebabkan pasar turun sehingga penjualan menurun otomatis laba pun turun, namun hasil penelitan penggunaan metode variable costing menunjukkan harga jual tinggi dibandingkan perhitungan harga jual dengan metode yang digunakan perusahaan artinya metode variabel tidak dapat mengatasi masalah.

Pada penelitian Kabib dkk (2017) dan Sari dan Fazli (2016), tempat yang diteliti mengalami masalah dimana harga jual yang terlalu rendah menyebabkan keuntungan menurun sementara peluang pasar ada untuk bisa lebih berkembang. Harga yang terlalu rendah menyebabkan laba yang rendah. Hasil perhitungan menggunakan metode variable costing menunjukkan harga jual lebih rendah jika dibandingkan perhitungan menggunakan metode yang digunakan perusahaan. Sehingga dapat disimpulkan metode variabel costing belum mampu mengatasi masalah yang dihadapi perusahaan.

Berdasarkan permasalahan tempat penelitian di UD. Sejahtera dan penelitian terdahulu yang memiliki perbedaan permaslaan dan tempat namun metode yang sama juga hasil penelitian masih belum menunjukkan bahwa metode variabel costing belum bisa diterapkan dalam penetapan harga jual. Oleh karena itu, peneliti tertarik ingin mengetahui apakah hasilnya sama seperti peneliti terdahulu atau mengasilkan kesimpulan yang berbeda. 


\section{TINJAUAN PUSTAKA}

\subsection{Akuntansi Biaya}

Menurut Supriyono (1999:12), akuntansi biaya adalah salah satu cabang akuntansi yang merupakan alat manajemen dalam memonitor dan merekam transaksi biaya secara sistematis, serta menyajikan informasi biaya dalam bentuk laporan biaya. Informasi akuntansi biaya sangat dibutuhkan oleh pihak manajemen perusahaan untuk aktivitas perencanaan, pengendalian, pengevaluasian dan pengambilan keputusan baik jangka pendek maupun jangka panjang.

\subsection{Biaya}

Menurut Mulyadi (2012:8), biaya adalah pengorbanan sumber daya ekonomis yang diukur dalam satuan uang yang telah terjadi atau yang kemungkinan akan terjadi untuk tujuan tertentu. Biaya dapat digolongkan sebagai berikut (Mulyadi, 2012:13):
a. Biaya menurut objek pengeluarannya.
b. Biaya menurut fungsi pokok perusahaan.

c. Biaya menurut hubungan biaya dengan sesuatu yang dibiayai.

d. Biaya menurut perilaku dalam hubungannya dengan perubahan volume aktivitas.

e. Biaya atas jangka waktu dan manfaat.

\subsection{Harga Pokok Produksi}

Harga Pokok Produksi (HPP) menurut pendapat Wijaksono (2006:10) adalah sejumlah aktiva yang apabila tahun berjalan aktiva tersebut dimanfaatkan untuk membantu memperoleh penghasilan. Sementara HPP menurut Sukrisno dan Trisnawati (2007:28) adalah semua biaya atas sejumlah barang yang selesai diproduksi pada periode tertentu Dari berbagai pendapat para ahli di atas maka dapat disimpulkan bahwa HPP adalah semua pengorbanan yang dilakukan perusahaan untuk memproduksi sejumlah produk.

\subsection{Harga Jual}

Harga jual menurut Hansen dan Mowen (2005:288) merupakan nilai moneter yang dibebankan oleh suatu 
unit usaha kepada pembeli atau pelanggan atas barang atau jasa yang dijual atau diserahkan. Harga jual merupakan sejumlah biaya yang dikeluarkan perusahaan untuk memproduksi suatu barang atau jasa ditambah dengan presentase laba yang diinginkan oleh perusahaan. Sehingga untuk pencapaian laba yang diinginkan oleh perusahaan salah satu cara yang dapat dilakukan adalah menarik minat beli konsumen dengan cara menetapkankan harga jual.

Mulyadi (2007) memiliki beberapa metode dalam penetapan atau penentuan harga jual, diantaranya adalah sebagai berikut:

a. Penetapan Harga Normal (Normal Pricing).

b. Cost Type Contract.

c. Penetapan harga jual khusus (Special Order Pricing).

d. Penetapan harga jual yang diatur pemerintah.

e. Profit Margin

\subsection{Penetapan Harga Jual dengan} Metode Normal Pricing

Menurut Mulyadi (2007) dalam keadaan normal, harga jual ditentukan atas biaya penuh masa yang datang dan ditambah atas laba yang diharapkan. Penentuan harga normal biasanya disebut dengan cost-plus pricing atas taksiran tambahan atas biaya penuh yang disebut dengan mark up. Taksiran biaya penuh dapat dilakukan dengan dua pendekatan yaitu full costing dan variable costing.

a. Pendekatan menggunakan metode Full Costing

Metode full costing merupakan pembebanan seluruh biaya-biaya produksi yang bersifat tetap maupun variabel kepada produk. Biaya yang dipengaruhi langsung oleh volume produk dan biaya nonproduk yaitu biaya administrasi dan umum serta biaya pemasaran sebagai biaya yang tidak dipengaruhi langsung oleh volume produk.

Berikut rumus perhitungan persentase mark up dapat dinyatakan dengan rumus di bawah ini:

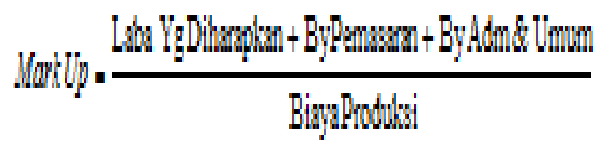

b. Pendekatan dengan metode Variable Costing

Dasar penetapan harga jual dengan metode variable costing 
menekankan penggolongan biaya berdasarkan perilakunya. Penentuan harga jual produk dan jasa ditentukan sebesar biaya variabel ditambah mark up yang harus tersedia untuk menutup semua biaya tetap dan menghasilkan laba yang diinginkan. Berikut rumus persentase mark up dinyatakan di bawah ini:

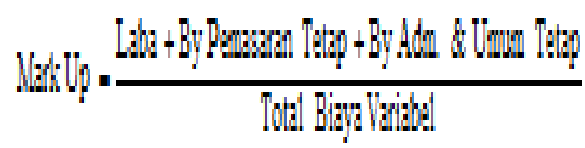

\subsection{Keuntungan}

Keuntungan disebut sebagai laba. Menurut Astuti (2005:12), keuntungan adalah perbedaan antara penghasilan dan biaya yang dikeluarkan. Adapun unsur unsur yang dikaji dalam analisis keuntungan yaitu besarnya biaya dan besarnya penerimaan.

Dengan kata lain, keuntungan adalah selisih antara penerimaan dengan biaya yang dirumuskan:

$$
\pi=T R-T C
$$

\subsection{Kerangka Pemikiran}

Sesuai dengan tinjauan pustaka maka untuk menjawab permasalahan dalam penelitian ini peneliti menggambarkan kerangka pikir sebagai berikut:

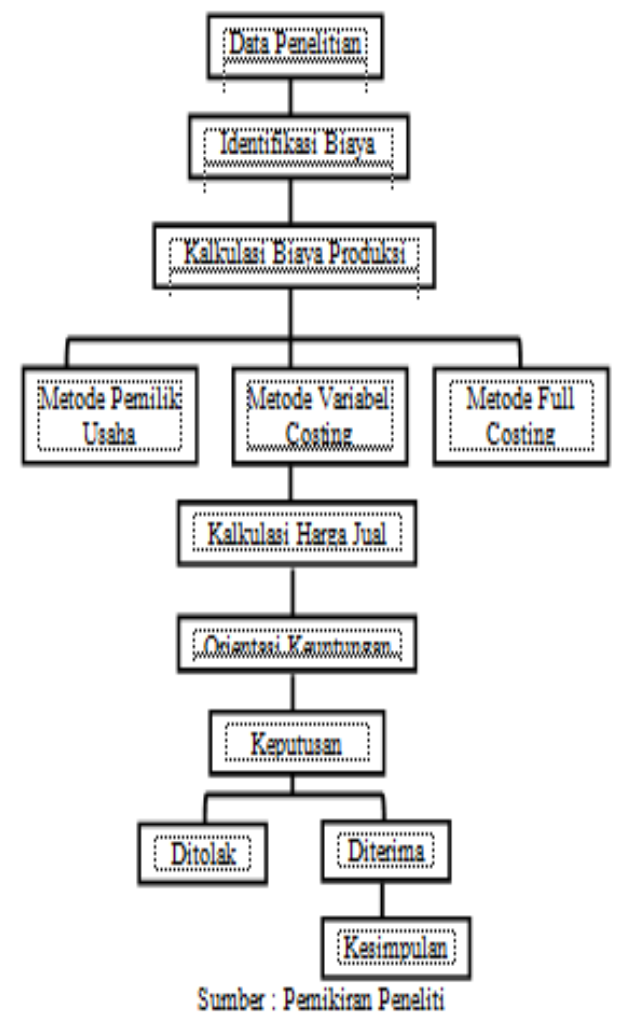

Gambar 1. Kerangka Pemikiran

Kerangka pemikiran diawali dengan perolehan data penelitian pada UD. Sejahtera Panti. Penelitian yang dilakukan dengan cara observasi, wawancara, dan dokumentasi.

Tahap berikutnya adalah pengidentifikasian biaya yang dikeluarkan oleh UD. Sejahtera. Setelah itu baru dikalkulasi jumlah biaya produksi sesuai dengan pilihan metode yang digunakan. Baru selanjutnya mengkalkulasi berapa 
harga jual yang seharusnya sesuai dengan metode yang digunakan.

Tahap berikutnya adalah orientasi keuntungan dengan mengaplikasikan laporan laba rugi dengan menggunakan semua metode apabila semua produk laku terjual.

\section{METODE PENELITIAN}

Penelitian ini dengan pendekatan studi kasus yang merupakan penelitian kualitatif. Lokasi penelitian pada UD. Sejahtera yaitu di Desa Serut, Kecamatan Panti, Kabupaten Jember. Penelitian awal dilakukan dengansurvei pendahuluan di bulan Juni tahun 2018. Penelitian dilanjutkan sampai dengan di bulan April 2019 untuk pengambilan data yang akan dianalisa dan data tentang sejarah perusahaan, sumber daya manusia yang beropersional, cara proses produksi, data bahan dan harga bahan yang digunakan untuk produksi, serta jumlah dan harga jual hasil produksi.

Objek utama penelitian ini yaitu laporan keuangan pada UD. Sejahtera. Khususnya mengenai laporan biaya produksi yang meliputi
Keputusan diambil dengan memilih pada perolehan keuntungan tertinggi. Selanjutnya memberikan kesimpulan tentang sebab dan akibat atas pengambilan tingkat keuntungan tersebut. Hingga diakhiri dengan tahap pengambilan keputusan.

biaya bahan baku, biaya tenaga kerja, dan biaya overhead pabrik serta biaya pemasaran dan biaya administrasi dan umum. Sementara itu untuk kelengkapan data adalah kondisional perusahaan UD. Sejahtera. Sehingga tehnik penelitian atau tata cara yang digunakan dalam penelitian antara lain menggunakan tehnik penelitian observasi, wawancara dan dokumentasi.

Sumber data dibedakan atas data primer dan data sekunder. Untuk pengambilan data wilayah dan sumber daya dalam penelitian ini berdasarkan data primer. Sedangkan data penelitian yang bersumber dari hasil dokumentasi UD. Sejahtera, maka disebut dengan data sekunder. Analisa data dalam penelitian ini terdiri dari lima tahap, yaitu: 1) tahap identifikasi biaya; 2) tahap kalkulasi 
biaya produksi; 3) tahap orientasi keputusan; dan 5) tahap kesimpulan. keuntungan; 4) tahap pengambilan

\section{HASIL PENELITIAN DAN PEMBAHASAN}

\subsection{Identifikasi Biaya}

Biaya dikelompokkan jadi biaya produksi dan biaya usaha

1. Biaya produksi terdiri dari:

a. Biaya Bahan Baku (Aluminium)

Alumunium yang dipakai terdiri dari 4 jenis tipe aluminium tipe A1, A2, A3 dan A4. Total pembelian aluminium adalah 225 lembar senilai Rp 48.988.800,- per bulan. Di bulan Maret 2019 mempunyai sisa kumulatif sebanyak 15 lembar senilai Rp3.039.120,-. $\quad$ Sehingga penggunaan bahan baku aluminium selama tiga bulan adalah tiga kali $\mathrm{Rp}$ 48.988.800,- dikurangi Rp 3.039.120,- menjadi sebanyak Rp143.927.280,- .

b. Biaya Tenaga Kerja Langsung

Biaya upah untuk memproduksi setiap jenis produk peralatan rumah tangga. Biaya tenaga kerja langsung yang dikeluarkan oleh UD. Sejahtera selama tiga bulan yaitu sejak Januari 2019 sampai dengan Maret 2019 sebesar Rp 49.500.000,.

c. Biaya Overhead Pabrik

Biaya Overhead Pabrik (BOP) dibedakan atas BOP variabel dan BOP tetap. BOP variabel meliputi biaya bahan penolong yang digunakan sebagai bahan pelengkap. Bahan penolong yang termasuk BOP variabel terdiri atas kawat, kaca, kayu bubut dan keling.

Diketahui untuk BOP variabel di bulan Januari Rp. 17.901.747,- kemudian di bulan Februari Rp. 17.848.306,- dan di bulan Maret yaitu Rp. 19.567.408 maka BOP variabel selama 3 bulan yaitu Rp. 55.317.461,-Untuk BOP tetap meliputi biaya penyusutan semua 
peralatan bagian produksi yang dapat diperhitungkan. Untuk bulan Januari Rp. 2.110.606,- pada bulan Februari Rp. 2.103.250,- dan pada bulan Maret Rp. 2.282.444,- maka BOP tetap untuk 3 bulan yaitu Rp. 6.496.300,--.

\section{Biaya Usaha}

Pengeluaran lain dari UD. Sejatera yang merupakan biaya usaha dalam bentuk biaya pemasaran juga biaya administrasi dan umum. Diketahui biaya pemasaran di bulan Januari yaitu 360.000,- untuk bulan Februari yaitu Rp. 360.000,- dan bulan Maret yaitu Rp. 390.000,-Kemudian untuk biaya administrasi dan umun diketahui di bulan Januari Rp. 5.437.450, di bulan Februari Rp. 5.435.450,- dan di bulan Maret yaitu Rp. 5.443.450,--

\subsection{Kalkulasi Biaya Produksi}

Biaya Produksi meliputi antara lain yaitu biaya bahan baku, biaya tenaga kerja langsung, biaya overhead pabrik variabel dan biaya overhead pabrik tetap. Biaya produksi untuk bulan Januari Rp.
82.737.793,- untuk bulan Februari Rp. 82. 563.596 dan di bulan Maret yaitu Rp. 89.939.651,-. Jadi biaya produksi selama 3 bulan yaitu Rp.255. 241.041,--

Harga pokok pesanan meliputi biaya bahan baku, biaya tenaga kerja langsung, biaya overhead pabrik variabel dan biaya overhead pabrik tetap. Harga pokok pesanan ini akan mengurangi pendapatan atau hasil penjualan pesanan, sehingga akan menghasilkan laba kotor atas penjualan pesanan. Harga pokok produksi di bulan Januari yaitu Rp.43.274.089,-- di bulan Februari Rp. 51.828.875,- dan di bulan Maret Rp. 93.962.112,-. Maka total selama 3 bulan yaitu Rp. 189.065.076,-.

Harga pokok penjualan tunai meliputi biaya bahan baku, biaya tenaga kerja langsung, biaya overhead pabrik variabel dan biaya overhead pabrik tetap. Harga pokok penjualan tunai ini akan mengurangi pendapatan atau hasil penjualan tunai, sehingga akan menghasilkan laba kotor atas penjualan tunai. Pada bulan Januari harga pokok jual tunai yaitu Rp. 15.195.360,- di bulan Februari Rp. 14.517.786,- dan di 
bulan Maret Rp. 30.843.858,-. Maka harga pokok jual tunai yaitu $\mathrm{Rp}$. 60.557.004,--

Setelah biaya produksi dikurangi harga pokok pesanan dan harga pokok jual maka nilai persediaan akhir, yaitu pada bulan Januari Rp. 24.268.344,- untuk bulan Februari Rp. 40.485.280,- serta untuk bulan Maret Rp. 5.861.961,-. Sehingga nilai persediaan akhir selama 3 bulan yaitu Rp. 5.861.961.

\subsection{Kalkulasi Biaya Usaha}

Biaya usaha merupakan jumlah dari biaya pemasaran dan biaya administrasi dan umum. Kedua biaya tersebut dibedakan biaya variabel dan biaya tetap. Yang artinya mengakumulasi biaya pemasaran, administrasi dan umum yang variabel dan tetap. Untuk memudahkan penghitungannya maka diketahui total biaya pemasaran di bulan Januari Rp. 1.818.700,- di bulan Februari Rp. 1.486.900,- dan di bulan Maret Rp. 2.313.000,-.

Untuk total biaya administrasi dan umum yaitu untuk bulan Januari Rp. 5.892.800,- kemudian di bulan Februari Rp. 5.786.000,- dan untuk
Maret yaitu Rp. 6.133.650,-. Apabila dijumlah maka biaya usaha UD. Sejahtera yaitu untuk bulan Januari Rp. 7.711.500,- untuk bulan Februari Rp. 7.272.900,- dan untuk bulan Maret yaitu Rp. 8.446.650,-.

\subsection{Orientasi Keuntungan}

Keuntungan yang diperoleh dapat diketahui dengan laporan laba rugi berdasarkan metode full costing maupun metode variabel costing.

Berdasarkan pendekatan metode full costing diperoleh laba bersih untuk 3 bulan yaitu untuk bulan Januari - Rp. 1.288.720,- untuk bulan Februari Rp. 8.829.121,- dan untuk bulan Maret yaitu $\mathrm{Rp}$. 78.163.398,-. Sehingga total laba bersih untuk 3 bulan yaitu Rp. 85.703.770,--.

Berbeda dengan hasil pendekatan menggunakan metode variabel costing untuk bulan Januari - Rp. 1.233.893,- kemudian untuk bulan Februari Rp. 8.891.304,- dan untuk bulan Maret Rp. 77.891.497,-Maka total laba bersih menurut pendekatan metode variabel costing dalah Rp. 85.548.907,-- 
Dari kedua metode di atas terjadi perbedaan hasil. Karena berdasarkan perolehan laba dengan dibandingkan harga pokok menunjukkan bahwa persentase laba metode full costing lebih kecil dibandingkan dengan metode variabel costing. Hal ini bisa dilihat pada tabel berikut:

Tabel 1. Perbedaan Prosentase Laba kedua Metode

\begin{tabular}{|c|c|c|c|c|}
\hline Y Laba & Januari & Fabruari & Maret & Jumlah \\
\hline FC d/d HPP & $-1,56 \%$ & $10,69 \%$ & $92,83 \%$ & $34,33 \%$ \\
\hline VC J/d HPP & $-1,53 \%$ & $11,05 \%$ & $94,77 \%$ & $35,16 \%$ \\
\hline FC a/d Jual & $-1,50 \%$ & $8,96 \%$ & $41,63 \%$ & $23,02 \%$ \\
\hline VC d/d Jual & $-1,43 \%$ & $9,02 \%$ & $41,53 \%$ & $22,96 \%$ \\
\hline
\end{tabular}

Sumber : Penghiturgan

Tabel 1 menunjukkan bahwa persentase laba metode full costing secara berangsur menjadi lebih besar dibandingkan dengan metode variabel costing. Dengan kondisi tersebut menunjukkan bahwa ada perbedaan perolehan laba atas dasar biaya usaha yang terdiri dari biaya pemasaran serta biaya administrasi dan umum. Perbedaan tersebut dengan kisaran sampai dengan $51,15 \%$ untuk metode full costing yang kurang dari $53,23 \%$ untuk metode variabel costing. Artinya dengan biaya yang semakin besar maka perolehan laba semakin kecil.

Hal ini dapat dijadikan tolok ukur atau batas minimal perolehan laba. Sehingga metode variabel costing dapat digunakan sebagai tolok ukur atau batas kritis perolehan laba.

\subsection{Kalkulasi Harga Jual}

Dalam penentuan harga penjualan sesuai dengan metode maka mempunyai dua metode yaitu metode full costing dan metode variabel costing. 
1. Mark up metode full costing sebagai berikut:

Tabel 2. Mark up Metode Full Costing

\begin{tabular}{|l|r|r|r|r|}
\hline \multicolumn{1}{|c|}{ Keterangan } & \multicolumn{1}{c|}{ Januari } & Februari & \multicolumn{1}{c|}{ Maret } & Jumlah \\
\hline Laba & -1.288 .720 & 8.829 .121 & 78.163 .369 & 85.703 .770 \\
By Pemaaran & 1.818 .700 & 1.486 .900 & 2.313 .000 & 5.618 .600 \\
ByAdm dan Umum & 5.892 .800 & 5.786 .000 & 6.133 .650 & 17.812 .450 \\
\hline By Produlai & 82.737 .793 & 82.563 .596 & 89.939 .651 & 255.241 .041 \\
Mart Upad TC & $7,76 \%$ & $19,50 \%$ & $96,30 \%$ & $42,76 \%$ \\
\hline HPP FC & 82.792 .620 & 82.625 .779 & 84.203 .681 & 249.622 .080 \\
Mark Lpa/d HPP & $7,76 \%$ & $19,49 \%$ & $102,86 \%$ & $43,72 \%$ \\
\hline
\end{tabular}

Sumber : Penghitungan

Berdasarkan metode full costing maka penentuan harga jual sebaiknya adalah dengan kisaran $43,72 \%$ dari tarif produksi.

2. Mark up metode variabel costing sebagai berikut:

Tabel 3. Mark up Metode Variabel Costing

\begin{tabular}{|c|c|c|c|c|}
\hline Keterangan & Januari & Februari & Marat & Jumlah \\
\hline Laba & -1.233 .893 & 8.891 .304 & 77.891 .497 & 85.548 .907 \\
\hline By Pemasaran Tetap & 360.00 & 360.000 & 390.000 & 1.110 .000 \\
\hline ByAdm \&U Tetap & 5.437 .450 & 5.435 .450 & 5.443 .450 & 16.316 .350 \\
\hline By Produlsi Var & 80.627 .187 & 80.460 .346 & 87.657 .208 & 248.744 .741 \\
\hline Mark $\mathrm{Up}$ a/d TC & $5,66 \%$ & $18,25 \%$ & $95,51 \%$ & $41,40 \%$ \\
\hline HPP VC & 80.627 .187 & 80.460 .346 & 82.193 .110 & 243.280 .643 \\
\hline Marl Lp a/d HPP & $5,66 \%$ & $18,25 \%$ & $101,86 \%$ & $42,33 \%$ \\
\hline
\end{tabular}

Berdasarkan metode variabel costing maka penentuan harga jual sebaiknya adalah dengan kisaran $42,33 \%$ dari tarif produksi. Apabila dipersentase dengan mark up untuk penentuan harga jual. Maka diketahui bahwa persentase mark up berdasarkan metode full costing mempunyai kisaran antara $10 \%$ sampai dengan $42 \%$. Sedangkan persentase mark up berdasarkan variabel costing mempunyai kisaran antara $12 \%$ sampai dengan $72 \%$.

Sehingga dapat diputuskan bahwa untuk membuat perusahaan akan lebih tangguh dalam melakukan pemasaran maka seharusnya tidak terlalu besar persentase mark up. Hal 
ini dikarenakan terlalu tingginya harga jual maka jumlah pemasaran turun. Pada akhirnya jumlah karyawan yang melakukan proses produksi juga turun, akibatnya jumlah produksi otomatis turun.

Dengan kondisi ini maka lebih baik menggunakan metode variabel costing, yang mempunyai angka mark up lebih tinggi, sehingga tingkat penurunan harga jual tidak terlalu curam.

\section{KESIMPULAN DAN SARAN}

\subsection{Kesimpulan}

Dari hasil ini analisa kualitatif sebagaimana pembahasan analisis maka peneliti memberikan kesimpulan bahwa

1. Biaya produksi pada UD. Sejahtera Kecamatan Panti di tahun 2019 untuk bulan Januari sebesar Rp 82.737.793,- bulan Februari sebesar Rp 82.563.596,bulan Maret sebesar Rp 89.939.651,-. Sehingga selama tiga bulan dengan total biaya produksi Rp 255.241.041.

2. Biaya usaha pada UD. Sejahtera Kecamatan Panti di tahun 2019
Apabila harga jual terlalu tinggi maka terjadi penurunan kapasitas usaha, akibatnya profitabilitas dan popularitas usaha menurun. Oleh sebab itu sebaiknya harga jual agak diturunkan. Penurunan secara berangsur diawali dengan standar mark up yang terbesar. Standar mark up yang terlalu besar nampak pada metode variabel costing. Sehingga perusahaan seharusnya berkiblat dengan metode variabel costing dalam penetapan harga jual.

untuk bulan Januari sebesar Rp 5.892.800,- bulan Februari sebesar Rp 5.786.000,- bulan Maret sebesar Rp 6.133.650,-. Sehingga selama tiga bulan dengan total biaya produksi $\mathrm{Rp}$ 17.812.450.

3. Biaya pemasaran pada UD. Sejahtera Kecamatan Panti di tahun 2019 untuk bulan Januari sebesar Rp 1.818.700,- bulan Februari sebesar Rp 1.486.900,bulan Maret sebesar Rp 2.313.650,-. Sehingga selama tiga bulan dengan total biaya produksi Rp 5.618.,600,-. 
4. Keuntungan yang diperoleh UD. Sejahtera Kecamatan Panti di tahun 2019 untuk bulan Januari sebesar Rp 1.288.720,- bulan Februari sebesar Rp 8.829.121,bulan Maret sebesar Rp 78.163.369,-. Sehingga selama tiga bulan dengan total biaya produksi Rp 85.703.770,-.

5. Apabila metode full costing dibandingkan dengan metode variabel costing menunjukkan bahwa ada perbedaan perolehan laba atas dasar biaya usaha yang terdiri dari biaya pemasaran serta biaya administrasi dan umum. Perbedaan tersebut dengan kisaran sampai dengan $51,15 \%$ untuk metode full costing yang kurang dari 53,23\% untuk metode variabel costing. Artinya dengan biaya yang semakin besar maka perolehan laba semakin kecil. Hal ini dapat dijadikan tolok ukur atau batas minimal perolehan laba. Sehingga metode metode variabel costing dapat digunakan sebagai tolok ukur atau batas kritis perolehan laba.

6. Metode full costing dan variabel costing memiliki perbedaan hasil. Berdasarkan perolehan laba dengan dibandingkan harga pokok menunjukkan bahwa prosentase laba metode full costing lebih kecil dibandingkan dengan metode variabel costing. Berdasarkan hasil penelitian, metode full costing penetapan harga jual yang tepat adalah dengan kisaran $43,72 \%$ dari tarif produksi. Sedangkan metode variabel costing penentuan harga jual adalah dengan kisaran $42,33 \%$ dari tarif produksi. Artinya penentuan harga jual dengan full costing masih lebih tinggi.

\subsection{Saran}

Berdasarkan hasil penelitian penulis ingin memberikan saran pada tempat usaha yaitu, sebagai berikut:

1. Hendaknya pemilik usaha menurunkan harga atau menentukan harga tidak terlalu tinggi, sehingga tidak membuat jumlah pemasaran menurun. Penurunan harga dapat menggunakan metode variabel costing sehingga tingkat penurunan harga jual tidak terlalu 
curam, sehingga pemasukan dapat stabil.

2. Perlu dilakukan peningkatan popularitas tempat usaha dengan melakukan promo dengan harga murah atau menawarkan produk yang menarik sehingga konsumen tertarik untuk membeli produk UD. Sejahtera.

\section{DAFTAR PUSTAKA}

Astuti, Dewi. 2005. Manajemen Keuangan Perusahaan, Cetakan Pertama. Jakarta: Ghalia Indonesia.

Garrison, Ray H. dan W. Eric Norren. 2001. Akuntansi Manajerial, Buku Kedua Edisi Pertama. Terjemahan A. Totok Budisantoso. Jakarta: Salemba Empat.

Hansen, R. and M. Mowen. 2005. Akuntansi Manajemen. Jakarta: Salemba Empat.

Kabib, N., Nurrokhmini, A., dan Hastutik, T. 2017. Metode Variable Costing sebagai Dasar Penentuan Harga Jual Produk. The $5^{\text {th }}$ Urecol Proceeding, Universitas Ahmad Dahlan Yogyakarta, hal: 118-123.

Megawati, Ni Made Rahayu. 2018. Analisis Penerapan Metode Variable Costing dalam Perhitungan Harga Pokok Produksi untuk Penetapan Harga Jual Produk (Studi pada Pabrik Lilin Bali Star Candle Suwat, Giayar). Jurnal Jurusan Pendidikan Ekonomi UNDIKSHA, Vol. 10 No. 2, hal: 450-459.
Mulyadi. 2007. Akuntansi Biaya, Edisi 5. Yogyakarta: UPP STIM YKPN. . 2012. Akuntasi Biaya. Yogyakarta: Unit Penerbit dan Percetakan Sekolah Tinggi Ilmu Manajemen YKPN.

Samryn, L. M. 2012. Akuntansi Manajemen Informasi Biaya untuk Mengendalikan Aktifitas Operasi dan Investasi. Jakarta: Kencana.

Sari, Vanda Novita dan Fazli Syam BZ. 2016. Analisis Penerapan Metode Variable Costing dalam Menentukan Harga Pokok Produksi pada UKM di Banda Aceh. Jurnal Ilmiah Mahasiswa Ekonomi Akuntansi, Vol. 1 No. 2, hal: 103-126.

Sukrisno, Agus dan Estralita Trisnawati. 2007. Akuntansi Perpajakan. Jakarta: Salemba Empat.

Supriyono, R. A. 2002. Akuntansi Biaya dan Manajemen. Yogyakarta: Fakultas Ekonomi UGM. 